\title{
p53 as an Effector or Inhibitor of Therapy Response
}

\author{
Julien Ablain, ${ }^{1,2,3}$ Brigitte Poirot, ${ }^{1,2,3,4}$ Cécile Esnault, ${ }^{1,2,3}$ Jacqueline Lehmann-Che, ${ }^{1,2,3,4}$ \\ and Hugues de Thé $e^{1,2,3,4,5}$ \\ ${ }^{1}$ Université Paris Diderot, Sorbonne Paris Cité, Institut Universitaire d'Hématologie, Hôpital St. Louis, \\ 75475 Paris, France \\ ${ }^{2}$ INSERM UMR 944, Equipe Labellisée par la Ligue Nationale contre le Cancer, Hôpital St. Louis, \\ 75475 Paris, France \\ ${ }^{3}$ CNRS UMR 7212, Hôpital St. Louis, 75475 Paris, France \\ ${ }^{4}$ Assistance Publique des Hôpitaux de Paris, Oncologie Moléculaire, Hôpital St. Louis, 75475 Paris, France \\ ${ }^{5}$ Collège de France, 75005 Paris, France \\ Correspondence: hugues.dethe@inserm.fr
}

\begin{abstract}
Although integrity of the p53 signaling pathway in a given tumor was expected to be a critical determinant of response to therapies, most clinical studies failed to link p53 status and treatment outcome. Here, we present two opposite situations: one in which p53 is an essential effector of cure by targeted leukemia therapies and another one in advanced breast cancers in which p53 inactivation is required for the clinical efficacy of dose-dense chemotherapy. If p53 promotes or blocks therapy response, therapies must be tailored on its status in individual tumors.
\end{abstract}

\section{ACUTE PROMYELOCYTIC LEUKEMIA}

$A^{\text {cute promyelocytic leukemia (APL) is the }}$ Aonly example of a malignancy cured by targeted therapies (de Thé and Chen 2010; Chen et al. 2011). APL eradication is likely made possible by its genetic simplicity and stability, as well as the availability of very efficient targeted therapies (see below). The disease is driven by the PML/RARA fusion, often associated with activation of FLT3 signaling or Myc trisomy, which promote proliferation and survival in many myeloid malignancies. Expression of PML/RARA in hematopoietic progenitors ex vivo or in mice drives enhanced self-renewal together with the typical promyelocytic differentiation block ( $\mathrm{Du}$ et al. 1999; Piazza et al. 2001). Mechanistically, like many fusion proteins, PML/RARA exerts a double dominant negative effect on the pathways controlled by each of its constitutive moieties. RARA is a transcriptional regulator responsive to retinoic acid (RA). PML/RARA represses RARA targets. Moreover, through its ability to bind highly degenerate response elements, PML/RARA also represses signaling by multiple nuclear receptors (Kamashev et al. 2004; Martens et al. 2010). PML/RARA also interferes with PML

Editors: Guillermina Lozano and Arnold J. Levine

Additional Perspectives on The p53 Protein available at www.perspectivesinmedicine.org

Copyright (C) 2016 Cold Spring Harbor Laboratory Press; all rights reserved; doi: 10.1101/cshperspect.a026260

Cite this article as Cold Spring Harb Perspect Med 2016;6:a026260 
J. Ablain et al.

function. PML assembles into nuclear domains that concentrate a variety of enzymes and otherwise unrelated proteins to enhance their posttranslational modifications (Lallemand-Breitenbach and de Thé 2010). These PML nuclear bodies (NBs) are stress-responsive structures and PML is required for response to a wide variety of stresses (Wang et al. 1998; Dellaire and Bazett-Jones 2004). Specifically, PML is a redoxsensitive protein, which behaves as a reactive oxygen species (ROS) sensor (Jeanne et al. 2010; Zhang et al. 2010). PML oxidation elicits the polymerization of PML onto the nuclear matrix to form NBs (Sahin et al. 2014). This promotes the recruitment and SUMO-conjugation of partner proteins, yielding their transient sequestration within NBs, allowing other posttranslational modifications (ubiquitination, acetylation, phosphorylation, etc.) to take place. Thus, on oxidative stress, PML confers an immediate change in the posttranslational modifications of proteins associated with NBs.

PML/RARA expression deorganizes PML NBs (Daniel et al. 1993; Dyck et al. 1994; Koken et al. 1994). PML modulates p53 activity, particularly in response to oncogenic stress (see below). In APL, p53 mutations are very rare and PML/RARA expression was shown to blunt p53 activation, notably for senescence induction (Trecca et al. 1994; Insinga et al. 2004). This supported the idea that NB-disruption antagonizes p53 signaling and thus contributes to APL pathogenesis (Fig. 1). PML NBs also modulate E2F signaling (Vernier and Ferbeyre 2014). Thus, although the first models of oncogenic transformation by PML/RARA stressed the importance of the differentiation arrest through transcriptional silencing, recent studies have highlighted the central role of PML/RARA-mediated disruption of NBs and resulting proliferation boost (Occhionorelli et al. 2011; Gaillard et al. 2015).

\section{Targeting PML/RARA Function and Stability}

APL is clinically responsive to RA and arsenic trioxide. RA triggers terminal differentiation of APL blasts and transient clearance of the leukemia. Arsenic cures up to $70 \%$ of patients as single agent therapy, while the RA/arsenic com-

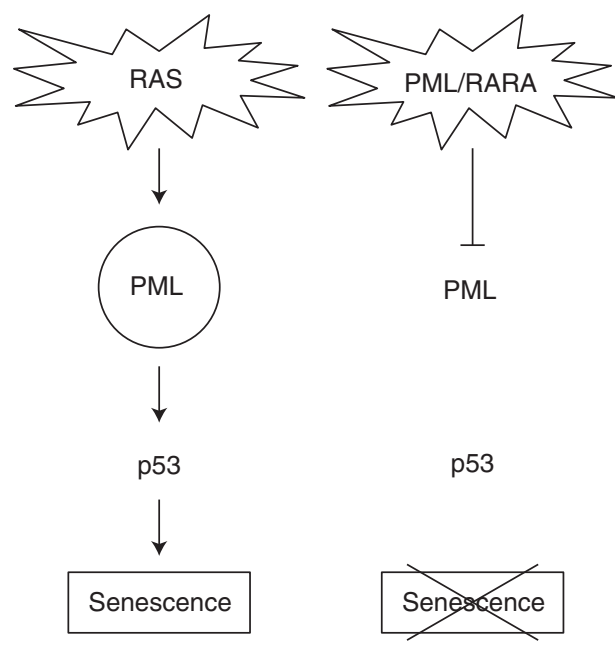

Figure 1. Expression of oncogenic RAS elicits PML nuclear body (NB) formation that subsequently triggers p53-mediated senescence. In contrast, PML/ RARA prevents oncogenic stress-induced senescence by sequestering PML and disrupting NBs, thus obliterating $\mathrm{p} 53$ response.

bination definitively cures virtually all patients in the absence of any chemotherapy (Lallemand-Breitenbach and de Thé 2013; Lo-Coco et al. 2013; Zhu and Huang 2014; de Thé 2015). Initial models aimed at understanding the action of RA all stressed the key role of transcriptional reactivation of PML/RARA in therapeutic response (Licht 2006). RA switches PML/ RARA from a constitutive repressor to a hormone-dependent transcription factor, remodeling the chromatin landscape toward a more open state and subsequently releasing the differentiation block (Licht 2009). Yet, the demonstration of the clinical efficacy of arsenic, and the unexpected observation that it also induces APL differentiation in vivo, but does not affect RA signaling, raised intriguing questions as to the basis for therapeutic response (Ablain and de Thé 2011).

The unexpected finding that both RA and arsenic target the stability of PML/RARA, by precipitating its degradation by the proteasome, provided a possible unifying mechanism for the activity of these two agents (Zhu et al. 1997, 2001). Indeed, PML/RARA degradation is the only shared biochemical property between 
these two otherwise unrelated agents. Studies performed in mouse models of APL have conclusively shown that PML/RARA loss is responsible for the abrogation of APL self-renewal (Nasr et al. 2008; Ablain et al. 2013, 2014). Subsequent studies showed that PML/RARA loss is actually sufficient for differentiation, thus explaining in vivo myeloid maturation on arsenic exposure (Vitaliano-Prunier et al. 2014).

Mechanistic studies aimed at understanding the biochemical basis for therapy-induced PML/RARA degradation revealed that RARA behaves as a RA-inducible degron (Zhu et al. 1999). This likely reflects a universal feedback mechanism wherein nuclear receptors undergo a postactivation degradation through a direct contact with $19 S$ proteasome. In contrast, arsenic targets PML (Zhu et al. 1997). Arsenic directly binds PML or PML/RARA and also indirectly induces their oxidation (Jeanne et al. 2010). This precipitates the formation of PML NBs and, through recruitment of the UBC9 SUMO-E2 ligase, favors the SUMOylation of PML and its associated proteins (LallemandBreitenbach et al. 2001; Sahin et al. 2014). Hypersumoylation of PML triggers recruitment of the SUMO-dependent ubiquitin ligase RNF4, PML, or PML/RARA polyubiquitination and proteasome-mediated degradation (Lallemand-Breitenbach et al. 2008; Tatham et al. 2008). Thus, in addition to changes in gene expression, therapy-induced PML/RARA loss restores the normal organization and function of PML NBs.

\section{p53, a Key Effector of APL Therapies}

Mouse models have played a critical role in deciphering the actual basis of APL eradication by the RA/arsenic combination. In particular, they allowed the detailed analysis of the early molecular and cellular events that occur on initiation of RA or arsenic therapy. The first major contribution of mouse models was to show that RA-induced differentiation could be uncoupled from long-term disease clearance. This was a major surprise in the field, as it profoundly questioned the concept of differentiation therapy (Ablain and de Thé 2011). This actually explained why RA and arsenic antagonize each p53 as Effector or Inhibitor of Therapy Response

other for differentiation (Shao et al. 1998), but sharply synergize for APL eradication in vivo (Lallemand-Breitenbach et al. 1999; Rego et al. 2000). The second essential step was the realization that differentiation is linked to transcriptional activation (or derepression), although loss of self-renewal is the direct consequence of PML/RARA loss (Nasr et al. 2008; Ablain et al. 2013). Subsequent studies indeed revealed that therapy-induced PML/RARA degradation triggers a p53 response. The latter is absolutely required for APL clearance, but not differentiation (Ablain et al. 2014; Bourdeau and Ferbeyre 2014).

\section{The Unexpected Role of Normal PML in Therapy Response}

Pioneering studies in the early 2000s showed that PML is an upstream activator of p53 signaling (Ferbeyre et al. 2000; Guo et al. 2000; Pearson et al. 2000). Although multiple studies have confirmed the essential role of PML as a p53 coactivator, how this is actually performed mechanistically remains ill-understood. A variety of mechanisms were proposed, including recruitment of the acetyltransferase CBP or sequestration of HDM2 (Bernardi et al. 2004). In fact, p53 and virtually all of its modifying enzymes may be located within PML NBs. Current views hold that PML forms a scaffold that recruits most p53 modifiers, hence integrating their afferent signals to finely tune p53 signaling, both in its nature and strength (Ivanschitz 2015). In the APL model, PML controls a specific subset of p53 targets implicated in senescence (Ablain et al. 2014). Indeed, PML is not only one of the most specific markers of senescent cells, it is also required for senescence induction in multiple systems (Vernier et al. 2011). Moreover, when overexpressed, a single PML splice variant controls p53 signaling and enforces senescence in primary cells, most likely through recruitment of p14ARF (Bischof et al. 2002; Ivanschitz et al. 2015). Finally, PML is transcriptionally induced on p53 activation, pointing to a feedforward, self-amplifying mechanism (de Stanchina et al. 2004).

Because PML NBs regulate p53 output, one could imagine that their reformation on 
J. Ablain et al.

PML/RARA degradation would be implicated in p53 activation. Indeed, PML/RARA-targeting agents reverse the block in 53 function imposed by the oncoprotein and activate a PML/ p53-dependent checkpoint with features of senescence (Fig. 2) (Ablain et al. 2014; Bourdeau and Ferbeyre 2014). Importantly, deletion of PML in APL cells abrogates therapy-induced loss of self-renewal and impedes activation of p53 targets. This model should therefore allow mechanistic explorations on the molecular basis for PML control over p53 activity. In particular, it is well suited to investigate whether specific PML-dependent p53 posttranslational modifications are required for the activation of this subset of target genes driving loss of self-renewal.

Arsenic is an extremely potent anti-APL drug, which targets both PML/RARA and PML. Although PML/RARA degradation is evidently beneficial to the disease, the unexpected demonstration of a key role of PML in conveying RA-response raised the tantalizing possibility that arsenic might also act on the normal PML protein to restore/enhance p53 signaling. The curative RA/arsenic treatment was long believed to reflect the more efficient degradation of PML/RARA by two independent proteolysis pathways (Ablain et al. 2011). Yet, arsenic-enhanced NB reformation through binding to the normal PML protein before its ultimate degradation could also participate in the striking synergy between the two agents. This proposal was strongly supported by the discovery of a mutation of normal PML in a therapy-resistant patient (Lehmann-Che et al. 2014). Remarkably, this mutation (A216V) (Jeanne et al. 2010), immediately adjacent to the arsenic-binding site, is the same as the one observed within PML/ RARA in arsenic-resistant patients (Goto et al. 2011; Zhu et al. 2014). Finally, p53 mutations have been reported in some therapy-resistant patients, notably the only ones from which cell lines could be derived (Lanotte et al. 1991; Karnan et al. 2006; Akagi et al. 2009). This may reflect intrinsic resistance of these p53 mutant primary APL cells to oxidative stress triggered by ex vivo culture, which otherwise would induce senescence and prevent long-term propagation.

These findings are important in at least three respects. First, they establish the first model in which p53 is directly implicated in cure by targeted therapies. In that respect, p53 activation also participates in response to Gleevec in animal models of chronic myelogeneous leukemias (Wendel et al. 2006). Second, they likely explain why arsenic is so potent as a single agent, through its ability to initiate PML/RARA deg-

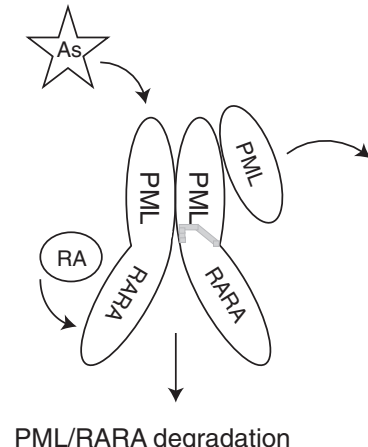

PML/RARA degradation by RA or arsenic (As)

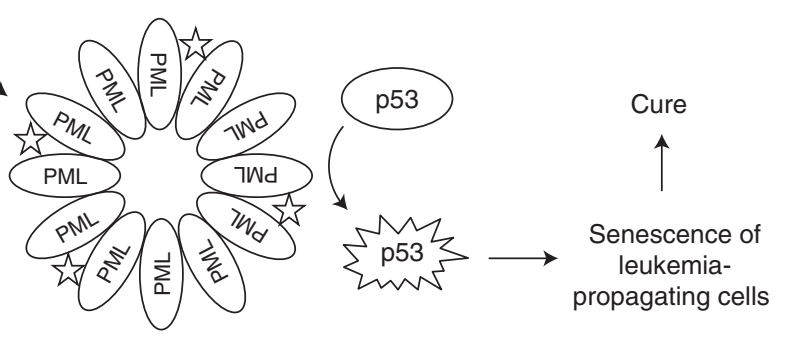

Passive NB reformation p53 activation active arsenic-enforced PML aggregation into NBs

Figure 2. Arsenic treatment of acute promyelocytic leukemia (APL) induces PML/RARA degradation by direct binding and oxidation, followed by SUMOylation and RNF4-dependent polyubiquitination. Retinoic acid (RA) targets the RARA part of PML/RARA and initiates its proteasome-dependent degradation. Loss of PML-RARA passive reformation of PML nuclear bodies (NBs). The latter is also enhanced by arsenic through its direct binding onto normal PML. Acute NB reformation triggers p53 activation, presumably via p53-modifying enzymes that reside in NBs, which initiates the senescence of APL cells and results in definitive disease elimination. 
p53 as Effector or Inhibitor of Therapy Response

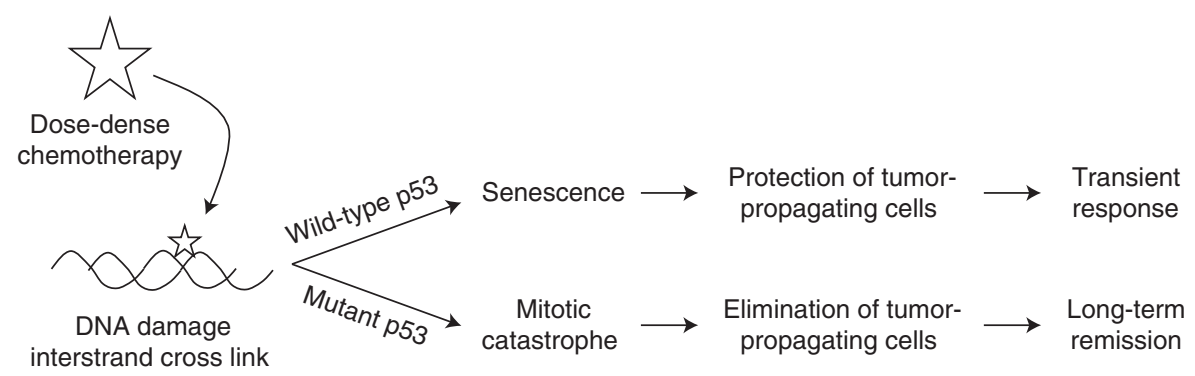

Figure 3. High-dose DNA-damaging chemotherapy showed significant clinical benefit in mutant p53 compared with wild-type $\mathrm{p} 53$ breast cancer patients. In cells with active $\mathrm{p} 53$ signaling, DNA damage induces senescence of cancer cells, which protects tumor-propagating cells from eradication. In contrast, in cells with nonfunctional p53, dose-dense chemotherapy triggers mitotic catastrophe and eliminates tumor-propagating cells, yielding long-lasting complete remissions.

radation and at the same time enforce PML nuclear body reformation by also acting on the normal PML allele. To our knowledge, this is the first example of a drug synergistically acting for on both an oncogene and tumor suppressor, which may explain its extraordinary clinical potency (Chen et al. 2011; de Thé et al. 2012). Third, the unambiguous involvement of normal PML in p53 activation in the context of RA or arsenic responses raises hopes that this checkpoint may be amendable to therapeutic interventions even when the PML gene is not rearranged.

Pharmacological harnessing of PML is possible, because expression of the gene is tightly regulated by interferons (Stadler et al. 1995). Moreover, NB aggregation is regulated by arsenic or other oxidative stresses (Zhu et al. 1997; Lallemand-Breitenbach et al. 2001; Sahin et al. 2014). Enforcing PML expression can facilitate SUMO-initiated proteolysis (Guo et al. 2014; Sahin et al. 2014; Dassouki et al. 2015). Interferon-induced senescence seems to require PML and is enforced by p53 (Chiantore et al. 2012; Fu et al. 2015). It is thus possible that interferontriggered PML/p53-mediated senescence may become a broad anticancer strategy, particularly in the context of minimal residual disease. In that respect, interferon $\alpha$ has yielded some clinical benefits in the pre-Gleevec periods of chronic myeloid leukemia (Preudhomme et al. 2010; Malagola et al. 2014). Similarly, the combination of interferon and arsenic, which enforces maximal NB formation and partner re- cruitment (Quignon et al. 1998), exerts clinical activity in HTLV-I associated adult T-cell leukemia (Kchour et al. 2009; Bazarbachi et al. 2011). This likely reflects the degradation of the HTLVI tax transactivator, an initiator, and a likely driver of ATL by a PML/SUMO/RNF4-dependent mechanism (El-Sabban et al. 2000; El Hajj et al. 2010; Dassouki et al. 2015). Clinical efficacy of this combination may also involve activation of a PML/p53 senescence checkpoint. The striking similitude between this model and APL suggests that the miracle of an APL cure by RA and arsenic may be transposed to some other conditions (de Thé 2015).

\section{p53 STATUS AND DNA-DAMAGING THERAPIES IN BREAST CANCERS}

Since the discovery that p53 was a key gene controlling thymocyte apoptosis in response to radiations (Lowe et al. 1993), a very large number of studies have addressed the link between tumor p53 status and response to DNA-damaging therapies. Taken the very high frequency of p53 inactivation in cancers (Kandoth et al. 2013) and the key role of this protein in DNA-damage response, tight connections between the p53 status of any given tumor, and clinical response to DNA-damaging therapies were expected. Yet, most studies have failed to establish any link. When addressing this key translational issue, one has to take a scientific perspective, integrating the following issues: what are the genetics of 
J. Ablain et al.

the disease, in particular how heterogeneous is it? What is exactly the molecular effect of the treatment administered? What is the clinical end-point considered (e.g., reduction in tumor size, partial or complete remission, tumor-free survival, overall survival)? How is p53 status determined (e.g., sequencing of mutations, assessment of protein level, functional assays, activation of downstream pathways)? When p53 has undergone a mutation, what is its functional consequence, as all mutations are not identical? Answering all of these questions is essential and significantly more complex than one may imagine at first glance.

A descriptive retrospective clinical study performed in our institution has unexpectedly unraveled a strict dependence of chemotherapy response on loss of p53 transcriptional activity, as determined using the functional yeast assay (Flaman et al. 1995). This specific assay is clearly more informative than p53 detection methods based on immunohistochemistry or first-generation DNA sequencing, although it usually fails to detect TP53 mutations with mRNA destabilization. Unexpectedly, in advanced breast cancers treated frontline with a dose-intense regimen containing the topoisomerase II inhibitor antracycline and the alkylator cyclophosphamide, complete pathological responses were only observed in p53 mutant tumors (Bertheau et al. 2002, 2007). This suggested that loss of p53-dependent transcriptional control was essential to the rapid tumor clearance. When trying to further refine the subgroup of responsive patients, it appeared that p53-mutant, estrogen-receptor-negative tumors were the most responsive to this regimen, with complete pathological responses reaching $70 \%$ in this subgroup (Lehmann-Che et al. 2010). Another study found that response to cisplatin is associated to loss of BRCA1 or TP53 nonsense or frame-shift mutations (Silver et al. 2010), supporting the idea that this group of tumor is exquisitely sensitive to DNA alkylation and strand cross-linking.

One should again stress the importance of the clinical end points. Immediate tumor regression is a very discriminative one, much less complex than survival. In our cohort of patients, complete remission was the best predictor for cure (Giacchetti et al. 2014). Dose-intense regimens are more likely to be p53 dependent than those involving standard doses (Lehmann-Che et al. 2010). These studies suggest that, as in myeloid leukemias (Fernandez et al. 2009), anthracyclin or cyclophosphamide dose intensification may be very beneficial in estrogen-negative, triple-negative, p53 mutant, or BRCA-1-like breast cancers, which are highly overlapping molecular subgroups (Silver et al. 2010; Giacchetti et al. 2014; Vollebergh et al. 2014; Schouten et al. 2015).

From a mechanistic point of view, these human studies were strongly backed by animal data, initially from xenograft and subsequently from genetically defined mouse models (Varna et al. 2009; Jackson et al. 2012). Collectively, they support a model wherein absence of p53-enforced $\mathrm{G}_{2} / \mathrm{M}$ checkpoint in p53-mutant tumor cells treated with chemotherapy allows crosslinked chromosomes to enter mitosis, precipitating mitotic catastrophe (Fig. 3). In cells with proficient p53 signaling, DNA-damaging therapy induces transient growth arrest and senescence, followed by rapid tumor regrowth (Varna et al. 2009; Jackson et al. 2012). Thus, p53 may hamper chemotherapy response in rapidly cycling cells.

\section{TOWARD AN INTEGRATED MODEL FOR p53 IN THERAPY RESPONSE}

Thanks to a better molecular characterization of human tumors and the availability of animal models, we are progressively glimpsing the molecular events that take place during cancer therapy. The picture is still blurred, but is progressively clearing. The two examples outlined above stress how varied the situation can be. More than ever, p53 appears to be a central actor in therapy outcome, a true "double-edged sword," depending on the tumor type and treatment administered (Bunz et al. 1999; Vogelstein and Kinzler 2001). Together with the high proliferation rate, intact p53 signaling is believed to play a role in the exquisite chemosensitivity of testicular seminomas (Riou et al. 1995). Multiple studies have similarly outlined the critical importance of $\mathrm{p} 53$ alterations in therapy resistance of chron- 
ic lymphocytic leukemia, myelodysplastic syndromes or acute myeloid leukemia (Zenz et al. 2010; Gonzalez et al. 2011; Bally et al. 2014).

We do not wish to infer from these examples that the solution is simple. Many translational studies suffer from confounding factors, including treatment and tumor heterogeneity and ambiguous determination of p53 function. Moreover, multiple ex vivo and in vivo models have rightfully stressed the complexity of the links between p53 status and therapy response. We would only like to highlight the fact that some clinical studies have observed that therapy response was tightly linked to p53 signaling, as expected from genetically clean and therapeutically simple mouse models. Years to come may see p53 status emerge as a key factor for therapeutic decisions. The most frequently altered gene in cancer may, in the end, emerge as the Achille's heel of tumor cells, provided we find the right arrows.

\section{ACKNOWLEDGMENTS}

The laboratory is supported by Collège de France, INSERM, CNRS, Université Paris-Diderot, Ligue Contre le Cancer, Institut National du Cancer, ANR (PACRI and SLI projects), Association pour la Recherche contre le Cancer (Griffuel Award to HdT), and Canceropôle Ile de France and the European Research Council (STEMAPL Advanced Grant to HdT).

\section{REFERENCES}

Ablain J, de Thé H. 2011. Revisiting the differentiation paradigm in acute promyelocytic leukemia. Blood 117: 5795-5802.

Ablain J, Nasr R, Bazarbachi A, de Thé H. 2011. Oncoprotein proteolysis, an unexpected Achille's Heel of cancer cells? Cancer Discovery 1: 117-127.

Ablain J, Leiva M, Peres L, Fonsart J, Anthony E, de Thé H. 2013. Uncoupling RARA transcriptional activation and degradation clarifies the bases for APL response to therapies. J Exp Med 210: 647-653.

Ablain J, Rice K, Soilihi H, de Reynies A, Minucci S, de Thé H. 2014. Activation of a promyelocytic leukemia-tumor protein 53 axis underlies acute promyelocytic leukemia cure. Nat Med 20: 167-174.

Akagi T, Shih LY, Kato M, Kawamata N, Yamamoto G, Sanada M, Okamoto R, Miller CW, Liang DC, Ogawa S, et al. 2009. Hidden abnormalities and novel classification of $\mathrm{t}(15 ; 17)$ acute promyelocytic leukemia (APL) based on genomic alterations. Blood 113: 1741-1748.

Bally C, Ades L, Renneville A, Sebert M, Eclache V, Preudhomme C, Mozziconacci MJ, de The H, Lehmann-Che J, Fenaux P. 2014. Prognostic value of TP53 gene mutations in myelodysplastic syndromes and acute myeloid leukemia treated with azacitidine. Leuk Res 38: 751-755.

Bazarbachi A, Suarez F, Fields P, Hermine O. 2011. How I treat adult T-cell leukemia/lymphoma. Blood 118: 17361745.

Bernardi R, Scaglioni PP, Bergmann S, Horn HF, Vousden KH, Pandolfi PP. 2004. PML regulates p53 stability by sequestering Mdm2 to the nucleolus. Nat Cell Biol 6: 665-672.

Bertheau P, Plassa F, Espie M, Turpin E, de Roquancourt A, Marty M, Lerebours F, Beuzard Y, Janin A, de Thé $H$. 2002. Effect of mutated TP53 on response of advanced breast cancers to high-dose chemotherapy. Lancet 360: 852-854.

Bertheau P, Turpin E, Rickman DS, Espie M, de Reynies A, Feugeas JP, Plassa LF, Soliman H, Varna M, de Roquancourt A, et al. 2007. Exquisite sensitivity of TP53 mutant and basal breast cancers to a dose-dense epirubicin-cyclophosphamide regimen. PLoS Med 4: e90.

Bischof O, Kirsh O, Pearson M, Itahana K, Pelicci PG, Dejean A. 2002. Deconstructing PML-induced premature senescence. EMBO J 21: 3358-3369.

Bourdeau V, Ferbeyre G. 2014. Engaging a senescent response to cure leukemia. Nat Med 20: 123-124.

Bunz F, Hwang PM, Torrance C, Waldman T, Zhang Y, Dillehay L, Williams J, Lengauer C, Kinzler KW, Vogelstein B. 1999. Disruption of p53 in human cancer cells alters the responses to therapeutic agents. J Clin Invest 104: 263269.

Chen SJ, Zhou GB, Zhang XW, Mao JH, de Thé H, Chen Z. 2011. From an old remedy to a magic bullet: Molecular mechanisms underlying the therapeutic effects of arsenic in fighting leukemia. Blood 117: 6425-6437.

Chiantore MV, Vannucchi S, Accardi R, Tommasino M, Percario ZA, Vaccari G, Affabris E, Fiorucci G, Romeo G. 2012. Interferon- $\beta$ induces cellular senescence in cutaneous human papilloma virus-transformed human keratinocytes by affecting p53 transactivating activity. PLoS ONE 7: e36909.

Daniel M-T, Koken M, Romagné O, Barbey S, Bazarbachi A, Stadler M, Guillemin M-C, Degos L, Chomienne C, de Thé H. 1993. PML protein expression in hematopoietic and acute promyelocytic leukemia cells. Blood 82: 18581867.

Dassouki Z, Sahin U, El Hajj H, Jollivet F, Kfoury Y, Lallemand-Breitenbach V, Hermine O, de Thé $\mathrm{H}$, Bazarbachi A. 2015. ATL response to arsenic/interferon therapy is triggered by SUMO/PML/RNF4-dependent Tax degradation. Blood 125: 474-482.

Dellaire G, Bazett-Jones DP. 2004. PML nuclear bodies: Dynamic sensors of DNA damage and cellular stress. Bioessays 26: 963-977.

de Stanchina E, Querido E, Narita M, Davuluri RV, Pandolfi PP, Ferbeyre G, Lowe SW. 2004. PML is a direct p53 target that modulates p53 effector functions. Mol Cell 13: $523-$ 535 . 
J. Ablain et al.

de Thé H. 2015. Lessons taught by acute promyelocytic leukemia cure. Lancet 386: 247-248.

de Thé H, Chen Z. 2010. Acute promyelocytic leukaemia: Novel insights into the mechanisms of cure. Nat Rev Cancer 10: 775-783.

de Thé H, Le Bras M, Lallemand-Breitenbach V. 2012. The cell biology of disease: Acute promyelocytic leukemia, arsenic, and PML bodies. J Cell Biol 198: 11-21.

Du C, Redner RL, Cooke MP, Lavau C. 1999. Overexpression of wild-type retinoic acid receptor $\alpha(\operatorname{RAR} \alpha)$ recapitulates retinoic acid-sensitive transformation of primary myeloid progenitors by acute promyelocytic leukemia RAR $\alpha$-fusion genes. Blood 94: 793-802.

Dyck JA, Maul GG, Miller WH, Chen JD, Kakizuka A, Evans RM. 1994. A novel macromolecular structure is a target of the promyelocyte-retinoic acid receptor oncoprotein Cell 76: 333-343.

El Hajj H, El-Sabban M, Hasegawa H, Zaatari G, Ablain J, Saab ST, Janin A, Mahfouz R, Nasr R, Kfoury Y, et al. 2010. Therapy-induced selective loss of leukemia-initiating activity in murine adult $\mathrm{T}$ cell leukemia. $J$ Exp Med 207: 2785-2792.

El-Sabban ME, Nasr R, Dbaibo G, Hermine O, Abboushi N, Quignon F, Ameisen JC, Bex F, de Thé H, Bazarbachi A. 2000. Arsenic-interferon- $\alpha$-triggered apoptosis in HTLV-I transformed cells is associated with tax downregulation and reversal of NF- $\mathrm{KB}$ activation. Blood 96: 2849-2855.

Ferbeyre G, de Stanchina E, Querido E, Baptiste N, Prives C, Lowe SW. 2000. PML is induced by oncogenic ras and promotes premature senescence. Genes Dev 14: 20152027.

Fernandez HF, Sun Z, Yao X, Litzow MR, Luger SM, Paietta EM, Racevskis J, Dewald GW, Ketterling RP, Bennett JM, et al. 2009. Anthracycline dose intensification in acute myeloid leukemia. N Engl J Med 361: 1249-1259.

Flaman JM, Frebourg T, Moreau V, Charbonnier F, Martin C, Chappuis P, Sappino AP, Limacher IM, Bron L, Benhattar J, et al. 1995. A simple p53 functional assay for screening cell lines, blood, and tumors. Proc Natl Acad Sci 92: 3963-3967.

Fu S, Wei J, Wang G, Wang B, Wang Y, Lai X, Huang H. 2015. The key role of PML in IFN- $\alpha$ induced cellular senescence of human mesenchymal stromal cells. Int J Oncol 46: 351-359.

Gaillard C, Tokuyasu TA, Rosen G, Sotzen J, Vitaliano-Prunier A, Roy R, Passegue E, de Thé H, Figueroa ME, Kogan SC. 2015. Transcription and methylation analysis of preleukemic promyelocytes indicate a dual role for PML/RARA in leukemia initiation. Haematologica 100: 1064-1075.

Giacchetti S, Porcher R, Lehmann-Che J, Hamy AS, de Roquancourt A, Cuvier C, Cottu PH, Bertheau P, Albiter M, Bouhidel F, et al. 2014. Long-term survival of advanced triple-negative breast cancers with a dose-intense cyclophosphamide/anthracycline neoadjuvant regimen. $\mathrm{Br} J$ Cancer 110: 1413-1419.

Gonzalez D, Martinez P, Wade R, Hockley S, Oscier D, Matutes E, Dearden CE, Richards SM, Catovsky D, Morgan GJ. 2011. Mutational status of the TP53 gene as a predictor of response and survival in patients with chronic lymphocytic leukemia: Results from the LRF CLL4 trial. J Clin Oncol 29: 2223-2229.

Goto E, Tomita A, Hayakawa F, Atsumi A, Kiyoi H, Naoe T. 2011. Missense mutations in PML-RARA are critical for the lack of responsiveness to arsenic trioxide treatment. Blood 118: $1600-1609$.

Guo A, Salomoni P, Luo J, Shih A, Zhong S, Gu W, Paolo Pandolfi P. 2000. The function of PML in p53-dependent apoptosis. Nat Cell Biol 2: 730-736.

Guo L, Giasson BI, Glavis-Bloom A, Brewer MD, Shorter J, Gitler AD, Yang X. 2014. A cellular system that degrades misfolded proteins and protects against neurodegeneration. Mol Cell 55: 15-30.

Insinga A, Monestiroli S, Ronzoni S, Carbone R, Pearson M, Pruneri G, Viale G, Appella E, Pelicci P, Minucci S. 2004. Impairment of $\mathrm{p} 53$ acetylation, stability and function by an oncogenic transcription factor. EMBO J 23: 11441154.

Ivanschitz L, Takahashi Y, Jollivet F, Ayrault O, Le Bras M, de Thé H. 2015. PML IV/ARF interaction enhances p53 SUMO-1 conjugation, activation and senescence. Proc Natl Acad Sci doi: 10.1073/pnas.1507540112.

Jackson JG, Pant V, Li Q, Chang LL, Quintas-Cardama A, Garza D, Tavana O, Yang P, Manshouri T, Li Y, et al. 2012. p53-mediated senescence impairs the apoptotic response to chemotherapy and clinical outcome in breast cancer. Cancer Cell 21: 793-806.

Jeanne M, Lallemand-Breitenbach V, Ferhi O, Koken M, Le Bras M, Duffort S, Peres L, Berthier C, Soilihi H, Raught $\mathrm{B}$, et al. 2010. PML/RARA oxidation and arsenic binding initiate the antileukemia response of $\mathrm{As}_{2} \mathrm{O}_{3}$. Cancer Cell 18: $88-98$.

Kamashev DE, Vitoux D, De Thé H. 2004. PML/RARARXR oligomers mediate retinoid and rexinoid/cAMP in APL cell differentiation. J Exp Med 199: 1-13.

Kandoth C, McLellan MD, Vandin F, Ye K, Niu B, Lu C, Xie M, Zhang Q, McMichael JF, Wyczalkowski MA, et al 2013. Mutational landscape and significance across 12 major cancer types. Nature 502: 333-339.

Karnan S, Tsuzuki S, Kiyoi H, Tagawa H, Ueda R, Seto M, Naoe T. 2006. Genomewide array-based comparative genomic hybridization analysis of acute promyelocytic leukemia. Genes Chromosomes Cancer 45: 420-425.

Kchour G, Tarhini M, Kooshyar MM, El Haji H, Wattel E, Mahmoudi M, Hatoum H, Rahimi H, Maleki M, Rafatpanah $\mathrm{H}$, et al. 2009. Phase 2 study of the efficacy and safety of the combination of arsenic trioxide, interferon $\alpha$, and zidovudine in newly diagnosed chronic adult Tcell leukemia/lymphoma (ATL). Blood 113: 6528-6532.

Koken MHM, Puvion-Dutilleul F, Guillemin MC, Viron A, Linares-Cruz G, Stuurman N, de Jong L, Szostecki C, Calvo F, Chomienne C, et al. 1994. The t $(15 ; 17)$ translocation alters a nuclear body in a RA-reversible fashion. EMBO J 13: 1073-1083.

Lallemand-Breitenbach V, de Thé H. 2010. PML nuclear bodies. Cold Spring Harb Perspect Biol 2: a000661.

Lallemand-Breitenbach V, de Thé H. 2013. Retinoic acid plus arsenic trioxide, the ultimate panacea for acute promyelocytic leukemia? Blood 122: 2008-2010.

Lallemand-Breitenbach V, Guillemin M-C, Janin A, Daniel M-T, Degos L, Kogan SC, Bishop JM, de Thé H. 1999. 
Retinoic acid and arsenic synergize to eradicate leukemic cells in a mouse model of acute promyelocytic leukemia. $J$ Exp Med 189: 1043-1052.

Lallemand-Breitenbach V, Zhu J, Puvion F, Koken M, Honore N, Doubeikovsky A, Duprez E, Pandolfi PP, Puvion E, Freemont P, et al. 2001. Role of promyelocytic leukemia (PML) sumolation in nuclear body formation, $11 \mathrm{~S}$ proteasome recruitment, and $\mathrm{As}_{2} \mathrm{O}_{3}$-induced PML or PML/ retinoic acid receptor $\alpha$ degradation. J Exp Med 193: 1361-1372.

Lallemand-Breitenbach V, Jeanne M, Benhenda S, Nasr R, Lei M, Peres L, Zhou J, Zhu J, Raught B, de Thé H. 2008. Arsenic degrades PML or PML-RAR $\alpha$ through a SUMOtriggered RNF4/ubiquitin-mediated pathway. Nat Cell Biol 10: $547-555$.

Lanotte M, Martin-Thouvenin V, Najman S, Balerini P, Valensi F, Berger R. 1991. NB4, a maturation inducible cell line with $\mathrm{t}(15 ; 17)$ marker isolated from a human acute promyelocytic leukemia (M3). Blood 77: 1080-1086.

Lehmann-Che J, Andre F, Desmedt C, Mazouni C, Giacchetti S, Turpin E, Espie M, Plassa LF, Marty M, Bertheau P, et al. 2010. Cyclophosphamide dose intensification may circumvent anthracycline resistance of p 53 mutant breast cancers. Oncologist 15: 246-252.

Lehmann-Che J, Bally C, de Thé H. 2014. Resistance to therapy in acute promyelocytic leukemia. New Engl J Med 371: 1171-1172.

Licht JD. 2006. Reconstructing a disease: What essential features of the retinoic acid receptor fusion oncoproteins generate acute promyelocytic leukemia? Cancer Cell 9: 73-74.

Licht D. 2009. Acute promyelocytic leukemia-Weapons of mass differentiation. $N$ Engl J Med 360: 928-930.

Lo-Coco F, Avvisati G, Vignetti M, Thiede C, Orlando SM, Iacobelli S, Ferrara F, Fazi P, Cicconi L, Di Bona E, et al. 2013. Retinoic acid and arsenic trioxide for acute promyelocytic leukemia. N Engl J Med 369: 111-121.

Lowe SW, Schmitt EM, Smith SW, Osborne BA, Jacks T. 1993. p53 is required for radiation-induced apoptosis in mouse thymocytes. Nature 362: 847-849.

Malagola M, Breccia M, Skert C, Cancelli V, Soverini S, Iacobucci I, Cattina F, Liberati AM, Tiribelli M, Annunziata $\mathrm{M}$, et al. 2014. Long-term outcome of $\mathrm{Ph}^{+} \mathrm{CML}$ patients achieving complete cytogenetic remission with interferon based therapy moving from interferon to imatinib era. Am J Hematol 89: 119-124.

Martens JH, Brinkman AB, Simmer F, Francoijs KJ, Nebbioso A, Ferrara F, Altucci L, Stunnenberg HG. 2010. PML-RAR $\alpha /$ RXR alters the epigenetic landscape in acute promyelocytic leukemia. Cancer Cell 17: 173-185.

Nasr R, Guillemin MC, Ferhi O, Soilihi H, Peres L, Berthier C, Rousselot P, Robledo-Sarmiento M, Lallemand-Breitenbach V, Gourmel B, et al. 2008. Eradication of acute promyelocytic leukemia-initiating cells through PMLRARA degradation. Nat Med 14: 1333-1342.

Occhionorelli M, Santoro F, Pallavicini I, Gruszka A, Moretti S, Bossi D, Viale A, Shing D, Ronzoni S, Muradore I, et al. 2011. The self-association coiled-coil domain of PML is sufficient for the oncogenic conversion of the retinoic acid receptor (RAR) $\alpha$. Leukemia 25: 814-820.

Pearson M, Carbone R, Sebastiani C, Cioce M, Fagioli M, Saito S, Higashimoto Y, Appella E, Minucci S, Pandolfi
PP, et al. 2000. PML regulates p53 acetylation and premature senescence induced by oncogenic Ras. Nature 406: 207-210.

Piazza F, Gurrieri C, Pandolfi PP. 2001. The theory of APL. Oncogene 20: 7216-7222.

Preudhomme C, Guilhot J, Nicolini FE, Guerci-Bresler A, Rigal-Huguet F, Maloisel F, Coiteux V, Gardembas M, Berthou C, Vekhoff A, et al. 2010. Imatinib plus peginterferon alfa-2a in chronic myeloid leukemia. $N$ Engl J Med 363: 2511-2521.

Quignon F, de Bels F, Koken M, Feunteun J, Ameisen J-C, de Thé H. 1998. PML induces a caspase-independent cell death process. Nature Genet 20: 259-265.

Rego EM, He LZ, Warrell RP Jr, Wang ZG, Pandolfi PP. 2000. Retinoic acid (RA) and $\mathrm{As}_{2} \mathrm{O}_{3}$ treatment in transgenic models of acute promyelocytic leukemia (APL) unravel the distinct nature of the leukemogenic process induced by the PML-RAR $\alpha$ and PLZF-RAR $\alpha$ oncoproteins. Proc Natl Acad Sci 97: 10173-10178.

Riou G, Barrois M, Prost S, Terrier MJ, Theodore C, Levine AJ. 1995. The $p 53$ and $m d m-2$ genes in human testicular germ-cell tumors. Mol Carcinog 12: 124-131.

Sahin U, Ferhi O, Jeanne M, Benhenda S, Berthier C, Jollivet F, Niwa-Kawakita M, Faklaris O, Setterblad N, de Thé H, et al. 2014. Oxidative stress-induced assembly of PML nuclear bodies controls sumoylation of partner proteins. J Cell Biol 204: 931-945.

Schouten PC, Marme F, Aulmann S, Sinn HP, van Essen HF, Ylstra B, Hauptmann M, Schneeweiss A, Linn SC. 2015. Breast cancers with a BRCA1-like DNA copy number profile recur less often than expected after high-dose alkylating chemotherapy. Clin Cancer Res 21: 763-770.

Shao W, Fanelli M, Ferrara FF, Riccioni R, Rosenauer A, Davison K, Lamph WW, Waxman S, Pelicci PG, Lo Coco F, et al. 1998. Arsenic trioxide as an inducer of apoptosis and loss of PML/RAR $\alpha$ protein in acute promyelocytic leukemia cells. J Natl Cancer Inst 90: 124-133.

Silver DP, Richardson AL, Eklund AC, Wang ZC, Szallasi Z, Li Q, Juul N, Leong CO, Calogrias D, Buraimoh A, et al. 2010. Efficacy of neoadjuvant Cisplatin in triple-negative breast cancer. J Clin Oncol 28: 1145-1153.

Stadler M, Chelbi-Alix MK, Koken MHM, Venturini L, Lee C, Saib A, Quignon F, Pelicano L, Guillemin M-C, Schindler C, et al. 1995. Transcriptional induction of the PML growth suppressor gene by interferons is mediated through an ISRE and a GAS element. Oncogene 11: 2565-2573.

Tatham MH, Geoffroy MC, Shen L, Plechanovova A, Hattersley N, Jaffray EG, Palvimo JJ, Hay RT. 2008. RNF4 is a poly-SUMO-specific E3 ubiquitin ligase required for arsenic-induced PML degradation. Nat Cell Biol 10: $538-$ 546.

Trecca D, Longo L, Biondi A, Cro L, Calori R, Grignani F, Maiolo AT, Pelicci PG, Neri A. 1994. Analysis of p53 gene mutations in acute myeloid leukemia. Am J Hematol 46: 304-309.

Varna M, Lehmann-Che J, Turpin E, Marangoni E, ElBouchtaoui M, Jeanne M, Grigoriu C, Ratajczak P, Leboeuf C, Plassa LF, et al. 2009. p53 dependent cell-cycle arrest triggered by chemotherapy in xenografted breast tumors. Int J Cancer 124: 991-997. 
J. Ablain et al.

Vernier M, Ferbeyre G. 2014. Complete senescence: RB and PML share the task. Cell Cycle 13: 696.

Vernier M, Bourdeau V, Gaumont-Leclerc MF, Moiseeva O, Begin V, Saad F, Mes-Masson AM, Ferbeyre G. 2011. Regulation of E2Fs and senescence by PML nuclear bodies. Genes Dev 25: 41-50.

Vitaliano-Prunier A, Halftermeyer J, Ablain J, de Reynies A, Peres L, Le Bras M, Metzger D, de Thé H. 2014. Clearance of PML/RARA-bound promoters suffice to initiate APL differentiation. Blood 124: 3772-3780.

Vogelstein B, Kinzler KW. 2001. Achilles' heel of cancer? Nature 412: 865-866.

Vollebergh MA, Lips EH, Nederlof PM, Wessels LF, Wesseling J, Vd Vijver MJ, de Vries EG, van Tinteren H, Jonkers J, Hauptmann M, et al. 2014. Genomic patterns resembling BRCA1- and BRCA2-mutated breast cancers predict benefit of intensified carboplatin-based chemotherapy. Breast Cancer Res 16: R47.

Wang Z-G, Ruggero D, Ronchetti S, Zhong S, Gaboli M, Rivi R, Pandolfi PP. 1998. PML is essential for multiple apoptotic pathways. Nat Genet 20: 266-272.

Wendel HG, de Stanchina E, Cepero E, Ray S, Emig M, Fridman JS, Veach DR, Bornmann WG, Clarkson B, McCombie WR, et al. 2006. Loss of p53 impedes the antileukemic response to BCR-ABL inhibition. Proc Natl Acad Sci 103: 7444-7449.

Zenz T, Eichhorst B, Busch R, Denzel T, Habe S, Winkler D, Buhler A, Edelmann J, Bergmann M, Hopfinger G, et al.
2010. TP53 mutation and survival in chronic lymphocytic leukemia. J Clin Oncol 28: 4473-4479.

Zhang XW, Yan XJ, Zhou ZR, Yang FF, Wu ZY, Sun HB, Liang WX, Song AX, Lallemand-Breitenbach V, Jeanne M, et al. 2010. Arsenic trioxide controls the fate of the PML-RAR $\alpha$ oncoprotein by directly binding PML. Science 328: $240-$ 243.

Zhu HH, Huang XJ. 2014. Oral arsenic and retinoic acid for non-high-risk acute promyelocytic leukemia. $N$ Engl J Med 371: 2239-2241.

Zhu J, Koken MHM, Quignon F, Chelbi-Alix MK, Degos L, Wang ZY, Chen Z, de Thé H. 1997. Arsenic-induced PML targeting onto nuclear bodies: implications for the treatment of acute promyelocytic leukemia. Proc Natl Acad Sci 94: 3978-3983.

Zhu J, Gianni M, Kopf E, Honore N, Chelbi-Alix M, Koken M, Quignon F, Rochette-Egly C, de Thé H. 1999. Retinoic acid induces proteasome-dependent degradation of retinoic acid receptor $\alpha(\operatorname{RAR} \alpha)$ and oncogenic RAR $\alpha$ fusion proteins. Proc Natl Acad Sci 96: 14807-14812.

Zhu J, Lallemand-Breitenbach V, de Thé H. 2001. Pathways of retinoic acid- or arsenic trioxide-induced PML/RAR $\alpha$ catabolism, role of oncogene degradation in disease remission. Oncogene 20: 7257-7265.

Zhu HH, Qin YZ, Huang XJ. 2014. Resistance to arsenic therapy in acute promyelocytic leukemia. $N$ Engl J Med 370: $1864-1866$. 


\section{$\& \mathrm{CSH} \&$ Cold Spring Harbor

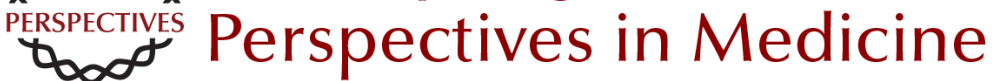

\section{p53 as an Effector or Inhibitor of Therapy Response}

Julien Ablain, Brigitte Poirot, Cécile Esnault, Jacqueline Lehmann-Che and Hugues de Thé

Cold Spring Harb Perspect Med 2016; doi: 10.1101/cshperspect.a026260 originally published online December 4, 2015

\section{Subject Collection The p53 Protein}

Targeting the MDM2-p53 Protein-Protein Interaction for New Cancer Therapy: Progress and Challenges

Shaomeng Wang, Yujun Zhao, Angelo Aguilar, et al.

Structural Evolution and Dynamics of the p53

Proteins

Giovanni Chillemi, Sebastian Kehrloesser,

Francesca Bernassola, et al.

Exploiting the p53 Pathway for Therapy

Chit Fang Cheok and David Philip Lane

The Regulation of Cellular Functions by the p53 Protein: Cellular Senescence

Crystal A. Tonnessen-Murray, Guillermina Lozano and James G. Jackson

The Transactivation Domains of the p53 Protein Nitin Raj and Laura D. Attardi

The Evolution of the Ribosomal Protein-MDM2p53 Pathway

Chad Deisenroth, Derek A. Franklin and Yanping Zhang

Somatic TP53 Mutations in the Era of Genome

Sequencing

Pierre Hainaut and Gerd P. Pfeifer

The Paradox of p53: What, How, and Why? Yael Aylon and Moshe Oren
Control of Cellular Aging, Tissue Function, and Cancer by p53 Downstream of Telomeres Caitlin M. Roake and Steven E. Artandi

Inherited TP53 Mutations and the Li -Fraumeni Syndrome

Tanya Guha and David Malkin

TP53 Mutations in Hypodiploid Acute Lymphoblastic Leukemia

Evan Q. Comeaux and Charles G. Mullighan

Transcriptional Regulation by Wild-Type and

Cancer-Related Mutant Forms of p53

Neil T. Pfister and Carol Prives

The Inherited p53 Mutation in the Brazilian Population

Maria Isabel Achatz and Gerard P. Zambetti

TP53 Mutations in Breast and Ovarian Cancer Laxmi Silwal-Pandit, Anita Langerød and Anne-Lise Børresen-Dale

p53 and the Carcinogenicity of Chronic Inflammation

Andrei V. Gudkov and Elena A. Komarova

Oncogenic Mutant p53 Gain of Function

Nourishes the Vicious Cycle of Tumor

Development and Cancer Stem-Cell Formation

Yoav Shetzer, Alina Molchadsky and Varda Rotter

For additional articles in this collection, see http://perspectivesinmedicine.cshlp.org/cgi/collection/ 